\title{
PENGARUH STRATEGI ROTATING TRIO EXCHANGE DALAM PEMBELAJARAN AKTIF TERHADAP PEMAHAMAN KONSEP FISIKA PADA SISWA KELAS VIII SMP NEGERI 13 PALU
}

\author{
Nurjannah, Amiruddin Kade dan Muhammad Jarnawi
}

\author{
Jurusan Pendidikan MIPA \\ Fakultas Keguruan dan IImu Pendidikan Universitas Tadulako Palu
}

\begin{abstract}
Abstrak - Penelitian ini bertujuan untuk menguji adanya pengaruh strategi rotating trio exchange dalam model pembelajaran aktif terhadap pemahaman konsep fisika pada siswa kelas VIII SMP Negeri 13 Palu. Jenis penelitian yang digunakan yaitu eksperimen kuasi dengan desain "The Equivalent Pretest-Posttest Design". Sampel dipilih menggunakan teknik purposive sampling. Kelas VIII C sebagai kelas eksperimen dan kelas VIII D sebagai kelas kontrol. Instrumen yang digunakan berupa tes pemahaan konsep fisika dalam bentuk esai yang telah divalidasi oleh ahli. Berdasarkan hasil pengolahan data, diperoleh rerata skor pretest pemahaman konsep fisika siswa kelas eksperimen adalah 12,86 dengan standar deviasi 2,44 , untuk rerata skor posttest adalah 20,77 dengan standar deviasi 2,49. Untuk kelas kontrol diperoleh rerata skor pretest 12,68 dengan standar deviasi 2,03, sedangkan untuk rerata skor posttest adalah 18,04 dengan standar deviasi 2,38. Analisis data dilakukan dengan teknik statistik uji-t dua pihak dengan taraf signifikan $\alpha=0,05$. Diperoleh nilai hasil thitung $=2,77$ dan $t_{\text {tabel }}=2,02$. Ini berarti bahwa nilai thitung berada diluar daerah penerimaan $\mathrm{H}_{\mathrm{o}}$. Hasil ini menunjukkan ada perbedaan antara kelas eksperimen dan kelas kontrol. Dengan demikian dapat disimpulkan bahwa, terdapat pengaruh strategi rotating trio exchange dalam pembelajaran aktif terhadap pemahaman konsep fisika pada siswa kelas VIII SMP Negeri 13 Palu.
\end{abstract}

Kata Kunci: strategi rotating trio exchange, pembelajaran aktif, pemahaman konsep fisika

\section{PENDAHULUAN}

Pelajaran fisika adalah pelajaran yang mengajarkan berbagai pengetahuan yang dapat mengembangkan daya nalar, analisa, sehingga hampir semua persoalan yang berkaitan dengan alam dapat dimengerti. Untuk dapat mengerti fisika secara luas, maka harus dimulai dengan kemampuan pemehaman konsep dasar yang ada pada pelajaran fisika. Berhasil atau tidaknya seorang siswa dalam memahami tentang pelajaran fisika sangat ditentukan oleh pemahaman konsep. Kesalahan konsep yang dialami oleh siswa dapat disebabkan oleh pemahaman awal dan pengalaman siswa, guru tidak menguasai bahan ajar, penjelasan yang keliru dari buku siswa, serta metode mengajar yang hanya berisi ceramah dan menulis [1].

Pemahaman artinya proses mendalami atau cara untuk mengetahui benar menunjukkan suatu kemampuan dimana kemampuan tersebut dapat diperlihatkan dengan jalan menejermahkan bahan tersebut dari suatu bentuk ke bentuk lain. Misalnya dari bentuk kata-kata menjadi simbol. Konsep merupakan abstraksi dari berbagai kejadian, objek, fenomena dan fakta. Konsep menjadi bagian penting yang harus dipahami dalam mempelajari fisika dan menguasai materi fisika secara utuh. Kurangnya pengetahuan mengenai konsep dapat menimbulkan terjadinya kesalahan konsep atau miskonsepsi. Pemahaman konsep fisika merupakan dasar bagi siswa untuk membangun kemampuan pemecahan masalah fisika[1].

Salah satu penyebab penguasaan fisika yang lemah ialah karena siswa hanya belajar pada pola permukaan (surface pattern matching learning), yaitu mendengarkan ceramah pengajar dan berlatih cara mengerjakan latihan soal. Siswa lebih mengutamakan cara menyelesaikan soal dibandingkan dengan memahami konsep dengan benar. Penguasaan materi fisika yang lemah disebkan oleh lemahnya pemahaman konsep fisika. Banyaknya rumus praktis menjadikan siswa lebih terfokus untuk menghafalkan rumus dari pada belajar memahaminya. Siswa lebih menyukai menyelesaikan soal hitung-hitungan yang menggunakan rumus praktis dibandingkan menyelesaikan soal berbentuk soal konsep [2].

Salah satu pembelajaran yang dapat di gunakan yaitu pembelajaran aktif dalam bentuk diskusi. Pembelajaran aktif (active learning) memiliki desain yang berbeda dari pembelajaran konvensional seperti penempatan tempat duduk, penempatan kelompok, pembelajaran yang menggunakan diskusi, pembelajaran dengan pemecahan masalah, dan lain sebagainya. Strategi pembelajaran yang dapat digunakan dalam pembelajaran aktif dengan sistem diskusi adalah rotating trio exchange [3].

Pembelajaran aktif dengan strategi rotating trio exchange merupakan strategi pembelajaran yang menumbuhkan partisipasi siswa menjadi aktif pada saat mengikuti kegiatan pembelajaran. Selain itu, partisipasi aktif siswa menjadi tempat bagi siswa untuk saling mengembangkan kemampuan dan saling memberikan pendapat untuk memperoleh kepastian jawaban dari anggota kelompok. Pembelajaran aktif dapat meningkatkan interaksi antar siswa dan taraf berfikir tingkat tinggi siswa [4]. 
Berdasarkan hasil penelitian sebelumnya [5-7] strategi rotating trio exchange dapat meningkatkan hasil belajar siswa. Sehingga peneliti ingin meningkatkan pemahaman siswa melalui kegiatan pembelajaran yang melibatkan siswa secara langsung serta berperan aktif. Oleh karena itu, penelitian ini di lakukan untuk mengkaji tentang pengaruh strategi rotating trio exchange dalam pembelajaran aktif terhadap pemahaman konsep fisika siswa kelas VIII SMP Negeri 13 Palu yang bertujuan untuk mengetahui ada tidaknya pengaruh strategi rotating trio exchange dalam pembelajaran aktif terhadap pemahaman konsep fisika siswa.

\section{METODE PENELITIAN}

Penelitian ini menggunakan metode eksperimen kuasi, dengan desain penelitian the equivalent pretest-posttest design yaitu menggunakan kelas-kelas yang sudah ada sebagai kelompoknya, dengan memilih kelaskelas yang sudah ada diperkirakan sama keadaan/kondisinya, dalam hal ini sama berdasarkan tingkat kecerdasan. Kemudian dilaksanakan pembelajaran dengan menggunakan strategi rotating trio exchange dalam pembelajaran aktif pada kelas eksperimen dan pada kelas kontrol diberikan model pembelajaran konvensional. Setelah pembelajaran selesai, dilakukan posttes untuk mengidentifikasi pemahaman konsep fisika pada kedua kelas (kelas eksperimen dan kelas kontrol) [8]. Adapun desain penelitiannya disajikan seperti pada Tabel1.

TABEL 1 DESAIN PENELITIAN THE EQUIVALEN PRETEST-POSTEST DESIGN

\begin{tabular}{cccc}
\hline Kelompok & Tes awal & Penelitian & Tes akhir \\
\hline Eksperimen & $\mathrm{O}_{1}$ & $\mathrm{X}$ & $\mathrm{O}_{1}$ \\
Kontrol & $\mathrm{O}_{1}$ & - & $\mathrm{O}_{1}$ \\
\hline
\end{tabular}

Keterangan:

$X$ :Strategi rotating trio exchange dalam pembelajaran aktif

$O$ : pretest dan posttest

Populasi yang digunakan pada penelitian ini adalah seluruh siswa kelas VIII yang terdiri dari 4 kelas dengan jumlah siswa 134 orang pada semester genap tahun ajaran 2017. Sampel dari penelitian ini adalah kelas VIIIC sebagai kelas eksperimen dan kelas VIIID sebagai kelas kontrol. Penarikan sampel pada penelitian ini ditentukan dengan menggunakan teknik purposive sampling atau penentuan sampel dengan pertimbangan tertentu.

Instrumen yang digunakan untuk melihat pemahaman konsep siswa. Tes yang digunakan berupa tes essay sebanyak 8 nomor soal yang dilakukan sebanyak dua kali pengujian, yaitu pada tahap awal sebelum perlakuan (pretest) dan tahap akhir setelah perlakuan (posttest). Tes ini sebelumnya divalidasi oleh validator ahli.

Data yang diperoleh dari penelitian ini selanjutnya diolah dengan menggunakan uji statistik berupa uji normalitas (Chi kuadrat), uji homogenitas (Fisher), dan uji hipotesis (uji-t dua pihak).

\section{HASIL DAN PEMBAHASAN}

\section{Hasil Penelitian}

Pengolahan data pretest dan posttest untuk masing-masing kelas yaitu kelas eksperimen dan kelas kontrol, diperoleh nilai maksimum, nilai minimum, nilai rata-rata dan standar deviasi. Seperti pada Tabel 2 berikut.

TABEL 2 DESKRIPSI SKOR TES PEMAHAMAN KONSEP SISWASISWA UNTUK KELAS EKSPERIMEN DAN KELAS KONTROL

\begin{tabular}{lcccc}
\hline \multirow{2}{*}{ Uraian } & \multicolumn{2}{c}{ Pre-test } & \multicolumn{2}{c}{ Post-test } \\
\cline { 2 - 5 } & Eksperimen & Kontrol & Eksperimen & Kontrol \\
\hline Sampel (n) & 22 & 22 & 22 & 22 \\
\hline Skori maksimum & 19 & 17 & 25 & 23 \\
\hline Skor minimum & 10 & 8 & 16 & 14 \\
\hline Skor rata-rata & 12,86 & 12,68 & 20,77 & 2,04 \\
\hline Standar deviasi & 2,44 & 2,03 & 2,49 & 2,38 \\
\hline
\end{tabular}

Uji normalitas data digunakan untuk mengetahui apakah populasi data berdistribusi normal atau tidak. Pengujian normalitas data posttest pada penelitian menggunakan uji Chikuadrat dengan kriteria penerimaan $X^{2}$ hitung $<X^{2}$ tabel, taraf signifikan $\alpha=0,05$, dan derajat kebebasan $\mathrm{dk}=\mathrm{k}-3$ hasil pengujian normalitas tes akhir antara kelas eksperimen maupun kelas kontrol dapat dilihat pada Tabel 3 . 
TABEL 3 HASIL UJI NORMALITAS POSTTEST KELAS EKSPERIMEN DAN KELAS KONTROL

\begin{tabular}{cccc}
\hline \multirow{2}{*}{ Uraian } & \multicolumn{3}{c}{ Posttest } \\
\cline { 2 - 4 } Sampel & Eksperimen & Kontrol \\
\hline$X^{2}$ hitung & 22 & 22 \\
\hline$X^{2}$ tabel & 2,82 & 0,68 \\
\hline Keterangan & & 5,99 \\
\hline
\end{tabular}

Dari tabel terlihat bahwa nilai $\mathrm{X}^{2}$ hitung kelas eksperimen maupun kelas kontrol lebih kecil daripada nilai $X^{2}(1-\alpha)(k-3)$. Artinya, hasil ini menunjukan bahwa data Posttest kelas eksperimen maupun kelas kontrol terdistribusi normal.
Pengujian data homogenitas ini menggunakan uji-F dengan kriteria jika $F_{\text {hitung }}<F_{\text {tabel }}$ maka data homogen. Hasil uji homogenitas dari kelas eksperimen dan kelas kontrol dapat dilihat pada Tabel 4.

TABEL 4 HASIL UJI HOMOGENITAS POSTTEST

Uraian Posttest Keterangan

\begin{tabular}{ccc}
\hline$F_{\text {hitung }}$ & 1,09 \\
$F_{\text {tabel }}$ & 2,83 & Homogen
\end{tabular}

Berdasarkan kriteria, dimana $F_{\text {hitung }}<F_{\text {tabel }}$ maka data tersebut bersifat homogenitas. Berdasarkan Tabel 4 dimana nilai $F_{\text {hitung }}<F_{\text {tabel. }}$. Hal ini menunjukkan bahwa data tersebut memiliki varians yang sama (homogen).
Setelah terpenuhinya uji normalitas dan homogenitas, maka dilakukan uji-t dua pihak. Hasil uji-t dapat dilihat pada Tabel 5

TABEL 5 UJI-T (DUA PIHAK) KELAS EKSPERIMEN DAN KELAS KONTROL

\begin{tabular}{cccccc}
\hline No & Kelas & $\bar{X}$ & $\mathrm{t}_{\text {hitung }}$ & $\mathrm{t}_{\text {table }}$ & Keputusan \\
\cline { 1 - 3 } & Kelas Eksperimen & 20,77 & 2,77 & 2,02 & $\mathrm{H}_{1}$ diterima \\
\hline 2 & Kelas Kontrol & 18,04 & & & \\
\hline
\end{tabular}

Berdasarkan data pada Tabel 5 thitung $(2,77) \geq$ tabel (2.02). Hal ini berarti, nilai thitung berada diluar daerah penerimaan $H_{0}$, dengan demikian $H_{0}$ ditolak dan $\mathrm{H}_{1}$ diterima. Hasil ini menyatakan terdapat pengaruh strategi rotating trio exchange dalam pembelajaran aktif terhadap pemahaman konsep fisika siswa.

\section{Pembahasan}

Penelitian ini bertujuan untuk mengetahui apakah terdapat pengaruh strategi rotating trio exchange dalam pembelajaran aktif terhadap pemahaman konsep fisika siswa. Pada awal penelitian kedua kelas terlebih dahulu diberikan pretest, tes awal (pretest) digunakan untuk mengetahui pengetahuan awal siswa sebelum diberi perlakuan. Sedangkan tes akhir (posttest) diberikan untuk mengetahui kemampuan akhir siswa di kedua kelas dan sebagai data analisis penelitian, yang selanjutnya digunakan sebagai pembanding untuk melihat apakah terdapat perbedaan pemahaman konsep antara kedua kelas tersebut pada materi kalor.

Berdasarkan hasil pengolahan data yang telah dilakukan, diketahui bahwa kemampuan awal siswa masih rendah. Sebelum kelas eksperimen diberi perlakuan para siswa memberi jawaban yang salah dan tanpa alasan yang ilmiah. Hal ini dapat dilihat dari pemberian tes awal (pretest) pada kelas eksperimen (VIII C) dengan skor ratarata sebesar 12,86 sedangkan skor rata-rata pada kelas kontrol (VIII D) adalah 12,68. Sementara berdasarkan analisis uiji-t diperoleh bahwa sebelum diberi perlakuan dalam proses 
pembelajaran, tidak ada perbedaan pemahaman konsep diantara kedua kelas tersebut. Hal ini menunjukkan bahwa kemampuan awal siswa dalam memahami konsep tentang Tekanan pada kedua kelas ini tidak berbeda.

Setelah kedua kelas ini diberikan perlakuan yang berbeda yakni strategi rotating trio exchange dalam model pembelajaran aktif pada kelas eksperimen dan pembelajaran konvensional di kelas kontrol. Sebagian besar siswa mampu menjawab soal dengan tepat dan dengan alasan yang ilmiah. Sedangkan pada kelas kontrol, tidak banyak siswa yang dapat menjawab soal dengan tepat. Untuk pemberian tes akhir (posttest) pencapaian skor rata-rata pada kelas eksperiman (VIII C) sebesar 20,77 sedangkan pada kelas kontrol (VIII D) sebesar 18,04. Dari hasil penelitian ini dapat dilihat bahwa skor rata-rata kelas eksperimen lebih tinggi dari pada kelas kontrol. Analisis uji-t menunjukkan bahwa setelah diberikan pembelajaran dengan strategi rotating trio exchange ada perbedaan pemahaman konsep kedua kelas tersebut.

Hasil tersebut menunjukkan bahwa pada materi tekanan, proses pembelajaran di kelas yang dilakukan dengan strategi rotating trio exchange dalam pembelajaran aktif akan mempengaruhi pemahaman konsep fisika siswa dibandingkan proses pembelajaran yang menggunakan pembelajaran konvensional. Pemahaman konsep pada kelas eksperimen dapat lebih baik dari pada kelas kontrol disebabkan oleh adanya perlakuan yang diberikan yaitu menyusun beberapa soal, membuat kelompok yang terdiri dari 3 orang, melakukan diskusi bersama teman kelompok dengan soal yang sama, persentase-persentase oleh kelompok masing-masing, setelah satu pertanyaan terselesaikan anggota kelompok akan bertukar tempat sesuai aturan dari strategi rotating trio exchange.

Adapun tahapan pembelajaran yang membuat pemahaman konsep kelas eksperimen meningkat yaitu pada saat pertukaran/rotasi anggota kelompok. Dengan adanya rotasi kelompok, siswa dapat melibatkan dirinya dalam bertukar pendapat dengan anggota kelompok yang baru terhadap berbagai pertanyaan yang diberikan guru setiap terjadinya rotasi. Pertukaran kelompok/rotasi kelompok memberikan ruang yang cukup luas bagi siswa untuk berdiskusi, serta mengolah informasi dengan anggota kelompok yang baru.

Persentase pemahaman konsep dikategorikan baik berkisar 76\%-100\%, cukup berkisar 56\%$75 \%$ dan kurang berkisar 0-55\% [9]. Pada indikator translasi dalam soal nomor 6 persentase pemahaman konsep fisika siswa kelas eksperimen memiliki tingkat persentase sebesar $72,73 \%$ dikaterogikan cukup sedangkan kelas kontrol memiliki tingkat persentase sebesar $53,41 \%$ dikatergorikan kurang. Pada indikator ini siswa dituntut untuk menerjemahkan kembali konsep Hukum Archimedes. Siswa terlatih untuk menemukan dan mengaitkan dari hasil kegiatan kedalam konsep yang dipelajari sehingga siswa mampu mentranslasi penjabaran konsep hukum Archimedes. Dari hasil tersebut dapat diketahui bahwa pemahaman siswa mengalami peningkatan walaupun tidak signifikan. Hal ini dikarenakan kekeliuran siswa dalam mengidentifikasi soal menyebebkan jawaban yang diberikan belum sesuai dengan konsep ilmiah.

Pada indikator interpretasi dalam soal nomor 7 persentase pemahaman konsep fisika siswa kelas eksperimen memiliki tingkat persentase sebesar $75,00 \%$ dikaterogikan cukup sedangkan kelas kontrol memiliki tingkat persentase sebesar $65,91 \%$ dikatergorikan cukup. Dari hasil tersebut dapat diketahui bahwa pemahaman siswa mengalami peningkatan walaupun tidak signifikan. Untuk soal nomor 8 dengan indikator yang sama persentase pemahaman konsep fisika siswa kelas eksperimen memiliki tingkat persentase sebesar $46,59 \%$ dikaterogikan kurang sedangkan kelas kontrol memiliki tingkat persentase sebesar $48,86 \%$ dikatergorikan kurang. Pada soal nomor 8 siswa dituntut untuk memahami suatu suatu konsep dalam kehidupan sehari-hari. Sulitnya siswa menjawab soal disebabkan kurangnya peneliti dalam memberikan penjelasan lengkap tentang aplikasi konsep dalam kehidupan seharihari, yang disebabkan waktu yang tidak mencukupi. Pemahaman konsep siswa jauh meningkat dibandingkan dengan sebelum diberikan perlakuan, namun masih terbatasi dengan aplikasi lainnya dengan kehidupan seharihari yang lebih rumit.

Pada indikator ekstrapolasi dalam soal nomor 4 persentase pemahaman konsep fisika siswa kelas eksperimen memiliki tingkat persentase sebesar $55,68 \%$ dikaterogikan kurang sedangkan kelas kontrol memiliki tingkat persentase sebesar $47,73 \%$ dikatergorikan kurang. Hal ini disebabkan kurangnya pemahaman siswa terhadap materi fisika yang telah dipelajari sebelumnya menyebabkan siswa mengalami kesulitan dalam menghubungkan konsep yang satu dengan yang lainnya.

Berbeda hal dengan kelas eksperimen, pada kelas kontrol proses pembelajarannya menggunakan pembelajaran konvensional yaitu ceramah. Pada pembelajaran ini siswa cenderung bersifat pasif, hanya menerima semua yang dijelaskan oleh guru dan mencatat hal-hal yang dianggap penting di papan tulis. Sementara kegiatan guru menyampaikan materi secara lisan. Selain itu ketika siswa diberikan kesempatan untuk mengajukan pertanyaan, mereka canggung untuk bertanya, ketidak aktifan siswa dalam proses pembelajaran menyebabkan siswa kurang termotivasi untuk menemukan konsep yang terkait materi yang diberikan. Selain itu, menyebabkan materi yang diterima kurang efektif 
sehingga mudah terlupakan dan pada akhirnya pemahaman konsep fisika siswa kurang berkembang.

Pelaksanaan strategi rotating trio exchange dalam pembelajaran aktif yang dilakukan peneliti tentunya juga memiliki kekurangan yang dapat terjadi di lapangan yaitu siswa mengalami kebingungan ketika diperintahkan untuk berputar searah maupun berlawanan jarum jam dengan kelompok trio, jumlah siswa yang terlalu banyak membuat siswa tidak dapat bekerja secara maksimal saat kegiatan pembelajaran.

Proses belajar mengajar di kelas eksperimen dan kelas kontrol sebenarnya mempunyai tujuan pembelajaran yang sama yaitu membuat siswa lebih mengerti tentang pelajaran yang diberikan oleh guru. Kedua kelas tersebut memiliki hasil belajar cukup tinggi setelah diterapkan model pembelajaran. Penerapan strategi rotating trio exchange dalam pembelajaran aktif akan menimbulkan keaktifan siswa, motivasi belajar, dan kerja sama dalam belajar sehingga siswa mendapat kesempatan untuk menemukan dan menetapkan ide mereka sendiri. Sedangkan pada kelas kontrol siswa cenderung lebih pasif. Perbedaan tersebut menyebabkan adanya pengaruh model pembelajaran yang digunakan pada kelas eksperimen dan kelas kontrol.

Berdasarkan penjelasan di atas dapat dilihat bahwa pemahaman konsep fisika pada siswa kelas eksperimen lebih baik dibandingkan kelas kontrol. Dapat dilihat bahwa kelas yang menggunakan strategi rotating trio exchange dalam pembelajaran aktif yaitu kelas eksperimen memiliki tingkat persentase yang cukup baik dibandingkan dengan kelas kontrol yang menggunakan pembelajaran konvensional. Hasil analisa data dari kedua kelas menunjukkan adanya pengaruh strategi rotating trio exchange dalam pembelajaran aktif terhadap pemahaman konsep fisika siswa pada konsep kalor.

\section{KESIMPULAN DAN SARAN}

\section{Kesimpulan}

Berdasarkan hasil penelitian dan analisis data yang diperoleh, maka dapat disimpulkan bahwa terdapat pengaruh strategi rotating trio exchange dalam pembelajaran aktif terhadap pemahaman konsep fisika siswa kelas VIII SMP Negeri 13 Palu. Hal ini dapat dilihat dari hasil pengujian hipotesis, $t_{\text {hitung }}>t_{\text {tabel }}$ atau $2,77>2.02$ atau $\mathrm{H}_{0}$ ditolak dan $\mathrm{H}_{1}$ diterima, yang berarti pengaruh strategi rotating trio exchange dalam pembelajaran aktif terhadap pemahaman konsep fsiska siswa.

Perbedaan ini disebabkan karena kelas eksperimen lebih aktif saat pembelajaran berlangsung sedangkan kelas kontrol lebih pasif saat pembelajaran berlangsung.

\section{Saran - Saran}

Berdasarkan hasil penelitian yang dilakukan, maka peneliti menyarankan kepada guru maupun calon guru yang ingin menggunakan strategi rotating trio exchange dalam pembelajaran aktif. Sebaiknya, dalam menggunakan strategi pembelajaran yang terpenting adalah keaktifan siswa dan motivasi belajarnya, sehingga merupakan tugas guru untuk meningkatkan hal tersebut. Peneliti mengharapkan adanya penelitian lain yang menggunakan strategi pembelajaran aktif dengan menggunakan metode-metode yang lebih inofatif.

\section{DAFTAR PUSTAKA}

[1] P. Suparno, Miskonsepsi dan Perubahan Konsep dalam Pendidikan Fisika. Jakarta : PT. Grasindo, 2005.

[2] Sabella dan Redish, Knowledge Activation and Organization in Physics Problem Solving. University of Maryland. 2007.

[3] M. Silberman, Active Learning 101 Strategi Pembelajaran Aktif, edisi ketiga. San Fransisco : Pfeiffer, 2006.

[4] T. Yerigen, "Journal of College Teaching \& Learning, Getting Active In The Classroom, vol. 5, no.6, 2008.

[5] A. Wulandari, "Jurnal Inovasi Pendidikan Fisika," Pembelajaran Aktif Melalui Strategi Rotating Trio Exchange terhadap Prestasi Belajar Siswa, vol.02, no. 03;6-10, 2013.

[6] W. Setiyani, M. Arif, dan E. Kurniawan, “ Jurnal Radiasi Pendidikan Fisika," Rotating Trio Exchange dengan Media Question Box terhadap Hasil Belajar Fisika, vol. 7, no. 01, 2015.

[7] S. Riza, R. Usman, dan Abdullah, "Jurnal Pendidikan Kimia," Rotating Trio Exchange disertai Question Box dapat Meningkatkan Prestasi Belajar Siswa, vol. 07, no. 05, 2015.

[8] Sugiyono, Metode Penelitian Kuantitatif, Penelitian Kualitatif, dan R\&D. Bandung : Alfabeta, 2014.

[9] S. Arikunto, Prosedur Penelitian Suatu Pendekatan Praktik, Jakarta : Rineka Cipta, 2006. 